\title{
Innowacje technologiczne we wdrażaniu e-usług dla przedsiębiorstw na przykładzie funkcjonowania Pojedynczego Punktu Kontaktowego
}

\begin{abstract}
Marcin Kowalczyk*
W artykule opisano ewolucje systemu e-usług skierowanych do przedsiębiorców. W pierwszej kolejności autor przytacza definicję cech charakterystycznych ustug oraz e-ustug. Następnie omawia wdrożenie Pojedynczego Punktu Kontaktowego (PPK), integrujacego zawartość informacyjna oraz wybrane e-ustugi i repozytorium procedur administracyjnych dla przedsiębiorców, jak również przedstawicieli organizacji pozarzadowych, obywateli, oraz urzędników realizujacych e-procedury dla przedsiębiorców. Nastęnie autor dokonat porównania stopnia zaawansowania stopnia rozwoju PPK w Polsce na tle pozostatych państw EOG. Artykut stanowi podsumowanie omówienia potencjalnych problemów rozwoju PPK w Polsce, zwiqzanych między innymi z koniecznościa niezbędnych dostosowań w ustawodawstwie, sankcjonujących wdrożenie elektronicznego obiegu dokumentów.
\end{abstract}

Słowa kluczowe: Pojedynczy Punkt Kontaktowy, EU-GO, e-usługi, Technologie Informacyjno-Komunikacyjne (ICT), e-urząd.

Nadesłany: 10.03.2016 | Zaakceptowany do druku: 20.06.2016

\section{Technical innovations in implementation of e-services for entrepreneurs, based on example of Point of Single Contact}

The article describes the evolution of e-services for entrepreneurs. First, the author cites the definition of the characteristics of services and e-services. In the following section, the article discusses the implementation of the Point of Single Contact (PSC) integrating information content, as well as providing selected e-services and the repository of administrative procedures for enterprises, as well as representatives of non-governmental organizations, citizens and officials implementing e-procedures for entrepreneurs. The author then compared the level of development of PSC in Poland compared to other EEA countries. Article summarizes the discussion of the potential problems of development of PSC in Poland, regarding necessary adjustments in the legislation, sanctioning the implementation of electronic circulation of documents.

Keywords: Point of Single Contact, EU-GO, e-services, Information and Communication Tachnology (ICT), e-government.

Submitted: 10.03.2016 | Accepted: 20.06.2016

JEL: O380

Dr Marcin Kowalczyk - Katedra Ekonomii i Administrowania Instytucjami Publicznymi, Wydział Prawa i Administracji, Uniwersytet Warmińsko-Mazurski w Olsztynie

Adres do korespondencji: ul. Warszawska 98, p. 102, 10-702 Olsztyn; e-mail: marcin.kowalczyk@uwm. edu.pl. 


\section{Wprowadzenie}

Artykuł ma na celu ukazanie procesów wdrażania Pojedynczego Punktu Kontaktowego (PPK) w Polsce, jako elektronicznego narzędzia umożliwiającego dopełnienie procedur związanych z podejmowaniem, wykonywaniem i zakończeniem działalności gospodarczej na terytorium Rzeczypospolitej Polskiej, jak również udzielanie informacji istotnych $\mathrm{z}$ punktu widzenia przedsiębiorców pragnących podjąć działalność gospodarczą w Polsce, podejmujących taką działalność lub planujących ją zakończyć. Towarzyszy temu dyskusja odnoszaca się do potencjalnych barier natury technologicznej i legislacyjnej przy wdrażaniu PPK w Polsce.

Autor artykułu przyjął następujące założenie badawcze: Elektronizacja procesu podejmowania, wykonywania i zakończania działalności gospodarczej za pośrednictwem Pojedynczego Punktu Kontaktowego napotyka $w$ Polsce liczne bariery zwiazane $z$ niedostosowaniem krajowego ustawodawstwa do potrzeb dynamicznie zmieniajacej się gospodarki, istotnie wplywajace na ograniczenie rozwoju e-ustug dla przedsiębiorców $w$ porównaniu $z$ innymi państwami Unii Europejskiej.

Przy podejmowaniu odpowiedzi na postawione powyżej pytanie badawcze autor posiłkował się analizą następujących aktów prawnych:

- Ustawa z dnia 2 lipca 2004 r. o swobodzie działalności gospodarczej, Dz. U. z 2004 r. Nr 173, poz. 1807

- Dyrektywa 2006/123/WE Parlamentu Europejskiego i Rady z 12 grudnia 2006 r. dotycząca usług na rynku wewnętrznym, Dz. Urz. L 376, 27.12.2006 r.

Metodą badawczą wykorzystaną w niniejszym opracowaniu była również analiza (studium) przypadku w odniesieniu do struktury Pojedynczego Punktu Kontaktowego w Polsce na tle podobnych narzędzi wykorzystywanych w innych państwach Unii Europejskiej, na podstawie danych zgromadzonych w dokumencie Single Market Scoreboard, Performance per governance tool, Points of Single Contact, wydanym przez agende unijna EU Internal Market and Services (Unijny Rynek Wewnętrzny i Usługi). Z punktu widzenia autora problem barier technologicznych i prawnych przy wdrażaniu PPK, skutkujących pogłębianiem dysproporcji $\mathrm{w}$ dostępie do nowoczesnych e-usług dla przedsiębiorców w Polsce uzasadnia podjęcie owej problematyki badawczej.

\section{Pojedynczy Punkt Kontaktowy jako specyficzny rodzaj e-usługi}

Punktem wyjścia do określenia cech charakterystycznych e-usług powinno być poprawne zdefiniowanie pojęcia „usługi”, w tym także „usługi publiczne”. Istotne charakterystyczne cechy usług zostały wskazane przez m.in. Audrey Gilmore. Zgodnie z ową charakterystyką usługi to:

- podstawowy produkt, komercyjny produkt organizacji usługowej, np. zorganizowane wczasy, polisa ubezpieczeniowa;

- produkt wzbogacony, czyli różnego rodzaju działania zmierzające do poprawy oferty produktu podstawowego, np. telefon zastępczy oferowany przez salon telefonii komórkowej na czas naprawy;

- wsparcie podstawowego produktu, dzialania skierowane na klienta lub produkt po dostarczeniu wyrobu, np. naprawy

- czyste działanie, wszelka aktywność skierowana na pomoc i służenie radą klientowi (Gilmore, 2006, s. 12).

Według Johna Stantona usługi definiuje się jako dające się wydzielić, zasadniczo niematerialne czynności, które stanowia zaspokojenie potrzeb i które niekoniecznie sa związane ze sprzedażą produktów lub innych usług. Świadczenie usług może wymagać (ale nie musi) zastosowania materialnych podmiotów. Jeśli nawet ich zastosowanie jest niezbędne, nie następuje zmiana właściciela tych przedmiotów (Stanton, 1981, s. 441). Zgodnie z definicją Philipa Kotlera usługa jest każda korzyść lub czynność, głównie niematerialna, świadczona jednej osobie przez drugą osobę, która jednocześnie nie zostaje właścicielem czegokolwiek (Kotler, 1982, s. 624, za: Czubała i in. 2006, s. 120-121). Jeszcze inne podejście do definicji usług uwzględnia Adrian Payne. W jego opinii usługa to każda czynność zawierajaca w sobie element niematerialności, która polega na oddziaływaniu na klienta lub przedmioty bądź nieruchomości znajdujące się w jego posiadaniu, a która nie powoduje przeniesienia prawa własności. Owo przeniesienie prawa własności może jednak nastąpić, a świadczenie usługi może być lub też nie być ściśle związane z dobrem materialnym (Payne, 1997, s. 20). Większa część defini- 
cji jakości usług skupia się wokół zaspokajania wymagań i oczekiwań klienta. Inne spojrzenie na sprecyzowanie tego terminu ma Christian Gronroos, który dzieli jakość usług na techniczną i funkcjonalną. Jakość techniczna, inaczej określana jako jakość wyjścia, w efekcie końcowym stanowi usługę i jest wynikiem relacji klienta z organizacją usługową. Jakość wyjściową usługi determinują czynniki takie jak: formalny przebieg procesu usługi, wyposażenie techniczne usługi, kwalifikacje personelu opierające się na właściwej dokumentacji. Jakość funkcjonalna usługi, tzw. jakość procesu, to wszystkie składowe części realizacji usługi. Składają się na nią: atmosfera, profesjonalizm, komunikatywność, kultura ludzi pracujących w organizacji, wygląd instytucji (Karaszewski, 2006, s. 20).

Usługi mają specyficzne cechy, które odróżniają je od produktów, wśród których należałoby wymienić:

- niematerialność - brak możliwości oceny jakości usług za pomocą zmysłów: wzroku, dotyku, smaku, zapachu czy słuchu. Zamiast tego przy ocenie jakości usług bierze się pod uwagę: atmosferę, wiedzę i nastawienie pracownika do usługobiorcy;

- nierozłączność - polega na równoczesnym procesie produkcji i konsumpcji usługi przy udziale konsumenta. Jakość usługi zależy nie tylko od doświadczenia, kwalifikacji i umiejętności usługodawcy, lecz także od wiedzy, zaangażowania usługobiorcy;

- różnorodność - duży wpływ czynnika ludzkiego przyczynia się do braku możliwości wykonania dwóch usług w identyczny sposób. Jest to efektem niemożliwości pełnej normalizacji zachowań ludzkich;

- brak możliwości magazynowania - brak możliwości przechowywania wiąże się z brakiem możliwości produkowania na zapas. W przypadkach, gdzie popyt jest stały lub charakteryzują go niewielkie wahania, brak możliwości magazynowania nie stanowi problemu. W sytuacji, w której popyt ulega fluktuacji, brak możliwości magazynowania może negatywnie wpłynąć na jakość usługi;

- niemożność przywłaszczenia - brak możliwości nabycia przez klienta prawa własności usługi, istnieje tylko możliwość do samej usługi i korzyści z nią związanych;

- indywidualizacja - podejście do każdej usługi indywidualnie, ponieważ wymagania i oczekiwania konsumentów dotyczące nawet takiej samej usługi mogą być nadzwyczajnie odmienne (Karaszewski, 2006, s. 18-19).

Przechodząc do kategorii e-usługi, jest ona identyfikowana jako rodzaj usługi (zgodnie $\mathrm{z}$ przytoczonymi powyżej kryteriami), która spełnia następujące warunki:

- jest świadczona w sposób częściowo lub całkowicie zautomatyzowany, dzięki zastosowaniu nowoczesnych technologii informacyjno-komunikacyjnych (ICT)

- jest realizowana w Internecie i za pośrednictwem Internetu,

- jest zindywidualizowana względem odbiorcy (personalizowana),

- strony świadczonej usługi znajdują się w różnych miejscach (usługa zdalna) (Śliwiński, http).

Według szerszej definicji e-usługa jest rozumiana jako nowa forma świadczenia usług przy wykorzystaniu Internetu, od momentu kontaktowania się firmy z klientem $w$ celu przedstawienia oferty poprzez zamówienie usługi, jej świadczenie i kontakt $\mathrm{z}$ klientem po wykonaniu usługi (Dąbrowska, Janoś-Kresło i Wódkowski, 2009, s. 41; Definicja elektronicznej usługi została zawarta również w Rozporządzeniu Ministra Rozwoju Regionalnego z dnia 29 stycznia 2009 roku).

E-usługi powinny się charakteryzować się następującymi cechami:

- prostotą, oznaczającą łatwość i intuicyjność korzystania z usług przez użytkownika,

- oryginalnością - e-usługa powinna stanowić coś nowego, czego dotąd nie było na rynku lub nowe rozwiązanie oparte na istniejących w gospodarce trendach,

- indywidualizacją i personalizacją, czyli dostosowaniem usługi do użytkownika i jego preferencji, przez co użytkownik odnosi wrażenie, że usługa jest skierowana bezpośrednio do niego,

- mobilnością, rozszerzeniem tradycyjnych e-usług oferowanych jako strony internetowe o nowe kanały dystrybucji, czyli rozwiązania na urządzenia mobilne (np. smartfonów, tablety) przeznaczone dla telewizji satelitarnej lub cyfrowej, 
- otwartością kodu, czyli dostępem do kodu źródłowego usługi, który może być modyfikowany na bieżąco przez społeczność internetową, pracującą nad ulepszeniami,

- uspołecznieniem, możliwością stworzenia e-społeczności wokół danej usługi,

- możliwością świadczenia w formie cloud computing lub rozwiązań webowych, co pozwala na redukcję problemów z kompatybilnością systemów operacyjnych czy back-up'em danych; dzięki tym technologiom potrzebne programy znajdują się na serwerach dostawcy: klient po swojej stronie ma dostęp do interfejsu (na ogół w postaci ujednoliconego środowiska pracy) poprzez program - klienta, np. przeglądarkę internetową (Komorowski $\mathrm{i}$ in., 2012).

Istotnymi udogodnieniami związanymi z zastosowaniem e-usług będą w szczególności:

- nowy sposób dostarczania usług - e-usługi pozwalają na płynne przesyłanie danych pomiędzy różnymi platformami, monitorowanie i utrzymanie urządzeń oraz podzespołów; firmy mogą sprawniej działać, jednocześnie zatrudniając mniejszą liczbę pracowników nadzorujących system, procesy i poszczególne urządzenia,

- postrzeganie informacji jako nowego źródła wartości - e-usługi pozwalają na podejmowanie istotnych działań operacyjnych na podstawie decyzji w tych gałęziach przemysłu, w których nawet niewielkie zmiany trendów zewnętrznych czy wydarzeń mają istotne znaczenie; głównie chodzi tu o transport, energie czy usługi finansowe,

- zorientowanie usług na klienta - nie ma ograniczeń co do ilości e-usług,

- e-usługi są bardziej zorientowane na indywidualizację obsługi, a klient bierze czynny udział w ich współtworzeniu,

- oferowanie mikrousług na żądanie przewiduje się, że w niedalekiej przyszłości e-usługi będą dostępne na każde żądanie (Dąbrowska, Janoś-Kresło i Wódkowski, 2009, s. 41-42).

W zależności od sposobu kontaktu na liniach administracja publiczna-obywatel i administracja publiczna-przedsiębiorstwo można wyróżnić cztery poziomy dojrzałości usług e-administracji:

- poziom informacyjny - urzędy publikują informacje w sieci WWW, a obywa- tele i przedsiębiorcy uzyskują potrzebne informacje, przegladajac serwisy internetowe urzędów na komputerach lub w specjalnych kioskach informacyjnych;

- poziom interakcyjny - obywatele i przedsiębiorcy komunikuja sie droga elektroniczną z pojedynczymi urzędami, ale urzędy niekoniecznie komunikują się z nimi drogą elektroniczną;

- poziom transakcyjny - obywatele i przedsiębiorcy komunikują się drogą elektroniczną z pojedynczymi urzędami, a urzędy również elektronicznie im odpowiadają;

- poziom integracyjny - portale internetowe udostępniają informacje $\mathrm{z}$ różnych urzędów i umożliwiaja realizację relacji na poziomie transakcyjnym (Jezierska, 2006; Sikora, 2004).

Według innej charakterystyki zawartej w publikacji zatytułowanej Jak skutecznie biznes może wykorzystać rozwiazania e-administracji, wydanej przez Polska Agencję Rozwoju Przedsiębiorczości, stopień rozwoju e-usług w Polsce uwzględnia następujące stadia rozwoju i dostępności e-usług:

- stadium 0: nie online,

- stadium 1: informacja,

- stadium 2: interakcja w jedną stronę,

- stadium 3: interakcja w dwie strony,

- stadium 4: transakcyjność.

Istotną cechą rozróżniającą wydaje się określenie w pierwszej przytoczonej charakterystyce poziomu integrującego, uwzględniającego możliwość świadczenia kompleksowych e-usług na poziomie pojedynczego punktu kontaktowego. Warunkiem koniecznym rozwoju usług e-administracji na poziomie integracyjnym według

R.A. Grytner jest zdefiniowanie:

- procedur załatwiania spraw administracyjnych (baza procedur),

- repozytorium formularzy wejściowych i wyjściowych (baza formularzy),

- zbioru aktów prawnych stanowiących podstawę realizacji procedur (baza aktów prawnych),

- typów organów i podmiotów korzystajacych z systemu elektronicznej administracji (baza typów organów) (Grytner, http).

Przytoczone wcześniej stadia rozwoju i dostępności e-usług zostały zaprezentowane na rysunku 1. 
Rysunek 1. Stadia dostępności e-usług

Stadium 0: NIE ONLINE

Stadium 1: INFORMACJA

Opis usługi udostępniony w internecie

Stadium 2: INTERAKCJA W JEDNĄ STRONĘ

Możliwość pobrania wniosku do wypełnienia i wydrukowania

Stadium 3: INTERAKCJA W DWIE STRONY

Możliwość złożenia wniosku drogą elektroniczną

\section{Stadium 4: TRANSAKCYJNOŚĆ}

Możliwość realizacji kompletnej usługi w sposób elektroniczny (uzyskanie odpowiedzi on-line z urzędu, możliwość realizowania płatności)

Źródło: Mamrot i Kośmider (2012).

\section{Pojedynczy Punkt Kontaktowy}

Zakres podstawowych zadań Pojedynczego Punktu Kontaktowego (PPK) zdefiniowano $\mathrm{w}$ art. $22 \mathrm{a}$ ust. 2 Ustawy $\mathrm{z}$ dnia 2 lipca 2004 r. o swobodzie działalności gospodarczej, (Dz. U. z 2004 r. Nr 173 poz. 1807):

Zadaniem punktu kontaktowego jest:

1) umożliwienie dopełnienia procedur związanych z podejmowaniem, wykonywaniem i zakończeniem działalności gospodarczej na terytorium Rzeczypospolitej Polskiej;

2) udzielanie informacji, o których mowa $\mathrm{w}$ art. 22b (zawartym poniżej) oraz art. 22d (informacje o adresach stron internetowych punktów kontaktowych w innych państwach $)^{1}$

Zgodnie z art. 22b ust. 1 ustawy o swobodzie działalności gospodarczej punkt kontaktowy ma za zadanie zapewnić dostęp do informacji dotyczących:

1) procedur i formalności wymaganych przy podejmowaniu, wykonywaniu lub zakończeniu działalności gospodarczej na terytorium Rzeczypospolitej Polskiej;

2) ogólnych zasad świadczenia usług w pań stwach, o których mowa w art. 13 ust. 1
(EOG, EFTA), w szczególności w zakresie ochrony konsumentów;

3) danych kontaktowych właściwych organów wraz ze wskazaniem zakresu ich kompetencji;

4) sposobów i warunków dostępu do rejestrów publicznych i publicznych baz danych dotyczących działalności gospodarczej i przedsiębiorców;

5) środków prawnych przysługujących w przypadku sporu między właściwym organem a przedsiębiorcą lub konsumentem, między przedsiębiorcą a konsumentem oraz między przedsiębiorcami;

6) wydanych lub opracowanych przez właściwe organy wyjaśnień w zakresie przepisów dotyczących podejmowania, wykonywania i zakończenia działalności gospodarczej;

7) danych kontaktowych stowarzyszeń i organizacji, które mogą udzielić praktycznej pomocy przedsiębiorcom lub konsumentom;

8) praw i obowiązków pracowników i pracodawców 2 .

Prowadzeniem Pojedynczego Punktu Kontaktowego (PPK) zajmuje się Ministerstwo Gospodarki. PPK w początkowej formie funkcjonował jako witryna interne- 
towa www.eu-go.gov.pl (obecnie jako www. biznes.gov.pl). W pierwotnej formie portal miał prezentować informacje odnoszące się do procedur administracyjnych związanych z prowadzeniem działalności gospodarczej, związane z:

- podejmowaniem działalności gospodarczej - KRS, CEIDG,

- uzyskiwaniem zezwoleń, pozwoleń, koncesji, wpisów do rejestru działalności regulowanej,

- uzyskiwaniem prawa do wykonywania zawodów regulowanych,

- uznawaniem kwalifikacji zawodowych,

- czasowym i transgranicznym świadczeniem usług (Mamrot i Kośmider, 2012, s. 8).

Głównym zadaniem Pojedynczego

Punktu Kontaktowego (PPK) ma być pomoc $\mathrm{z}$ dopełnianiu wszelkich formalności i procedur związanych z rozpoczynaniem i prowadzeniem działalności gospodarczej, w tym usługowej, zgodnie z dyrektywą usługową w której zaakcentowano umożliwienie zdalnej realizacji wspomnianych procedur i formalności.

Dyrektywa usługowa w swoich założeniach uwzględniała:

1) konieczność dokonania przeglądu i uproszczenia procedur administracyjnych związanych z prowadzeniem działalności usługowej przez państwa członkowskie,

2) obowiązek utworzenia pojedynczych punktów kontaktowych - jako kompleksowych podmiotów obsługi dla usługodawców przez państwa członkowskie,

3) prawo usługodawców i usługobiorców do łatwego dostepu poprzez pojedyncze punkty kontaktowe do określonych informacji na temat:

- wymogów, procedur i formalności, jakich należy dopełnić w celu podjęcia i prowadzenia działalności usługowej,

- danych kontaktowych organów właściwych w kwestiach związanych $\mathrm{z}$ podejmowaniem i prowadzeniem działalności usługowej,

- sposobów i warunków dostepu do rejestrów publicznych i publicznych baz danych dotyczacych usługodawców i usług,

- ogólnie dostepnych środków prawnych w razie sporu pomiędzy właściwymi organami a usługodawca lub usługobiorcą, lub między usługodawcą a usługobiorcą albo pomiędzy usługodawcami,

- danych kontaktowych stowarzyszeń lub organizacji (innych niż organy właściwe), które mogą udzielić praktycznej pomocy usługodawcom lub usługobiorcom.

4) zasady stosowania procedur realizowanych droga elektroniczna ${ }^{3}$

Zgodnie z pierwotnymi założeniami portal PPK miał być ściśle powiazany z ePUAP (Elektroniczną Platformą Usług Administracji Publicznej), co oznacza, że wszelkie elektroniczne procedury miały odbywać się zgodnie z regułami charakterystycznymi dla ePUAP, takimi jak:

1) wyszukanie sprawy (np. wydanie/zmiana/wydanie wtórnika świadectwa kierowcy, wydanie zezwolenia na obrót hurtowy alkoholem lub sprzedaż alkoholu, wydanie zezwolenia na wykonanie przewozów międzynarodowych, zatwierdzenie zakładu i wpis do zakładów podlegajacych kontroli organów Państwowej Inspekcji Sanitarnej, zgłoszenie obiektu do ewidencji obiektów hotelarskich, zamówienie zezwoleń na przewóz rzeczy, zgłoszenie powołania i odwołania administratora bezpieczeństwa informacji do rejestracji Generalnemu Inspektorowi Ochrony Danych Osobowych $)^{4}$,

2) wypełnienie wniosku; wybór danego wniosku przekierowuje użytkownika do formularza - wyświetla się kreator wysyłania dokumentu $\mathrm{w}$ formie elektronicznej, z pełną procedurą wypełnienia, podpisania i przesłania wniosku,

3) podpisanie wypełnionego wniosku. Dokument można podpisać na dwa sposoby: używając podpisu elektronicznego lub profilu zaufanego ${ }^{5}$,

4) przesłanie wniosku,

5) odebranie Urzędowego Poświadczenia Przedłożenia (UPP), tożsame z tradycyjnym dowodem nadania przesyłki lub dokumentu urzędowego,

6) odebranie wiadomości przez urząd,

7) przygotowanie odpowiedzi ze strony urzędu,

8) podpisanie odpowiedzi przez urzad,

9) przesłanie odpowiedzi użytkownikowi,

10) podpisanie i przesłanie przez użytkownika Urzędowego Poświadczenia Doreczenia (UPD),

11) odebranie odpowiedzi,

12) odebranie UPD przez urząd (Mamrot i Kośmider, 2012, s. 7-8). 
Funkcję polskiego punktu kontaktowego pełni portal www.eu-go.gov.pl (dostępny również pod adresem: www.biznes.gov.pl), z uporządkowaną strukturą treści, umożliwiajaca użytkownikowi sprawne wyszukiwanie informacji, dostępnych w języku zarówno polskim, jak i angielskim. W centralnym miejscu strony głównej witryny PPK (www.biznes.gov.pl) znajdują się trzy sekcje tematyczne: Dla przedsiębiorców, Dla obywateli, Dla administracji, ułatwiając potencjalnemu użytkownikowi segmentacje treści dostosowanej do jego indywidualnych zainteresowań i potrzeb. Główna witryna odsyła również zainteresowanych użytkowników do zakładek:

- poradniki przedsiębiorcy - istotne informacje dla osób zarówno rozpoczynajacych, prowadzących, jak i zamykających działalność gospodarcza oraz przedsiebiorców świadczących tymczasowe usługi w Polsce;

- znajdź procedurę - wyszukiwarka procedur odnoszących się m.in. do: uznawania kwalifikacji zawodowych, świadczenia usług transgranicznych, procedur związanych z zawodami regulowanymi, działalnością regulowana, zezwoleniami i innymi formami reglamentacji oraz pozostałymi kategoriami nieujętymi powyżej. Sekcja Przebieg procedury uwzględnia możliwość zapoznania się z każdym etapem realizacji (wyszczególnieniem dokumentów, jakie należy złożyć, terminów, których należy dotrzymać, oraz uczestników biorących udział w każdym kroku realizowania procedury administracyjnej) ${ }^{6}$;

- znajdź instytucję - wyszukiwarka m.in. instytucji centralnych, urzędów skarbowych, sądów, oddziałów ZUS, cechów i izb gospodarczych, jednostek samorządu terytorialnego, oraz pozostałych jednostek administracyjnych, zarówno na szczeblu krajowym, jak i regionalnym ${ }^{7}$;

- rejestry publiczne - rejestry uwzględniajace m.in. Ksiegi wieczyste on-line, Centralną Ewidencję i Informację o Działalności Gospodarczej, Krajowy Rejestr Sądowy, Rejestry Prowadzone przez: UOKiK, Ministerstwo Transportu, Budownictwa i Gospodarki Wodnej, Rejestry przedstawicielstw przedsiębiorców zagranicznych, Rejestr Operatorów Pocztowych, Rejestr Przedsiębiorców Telekomunikacyjnych, Rejestry i ewi- dencje na stronie Komisji Nadzoru Finansowego, Rejestr polskich adwokatów w Internecie, Krajowy Rejestr Karny;

- akademia ePK - portal e-szkoleń skierowanych do pracowników administracji, obywateli i przedsiębiorców, obejmujący m.in. szkolenia z zakresu:

- zasad obsługi i korzystania z portalu PPK,

- obsługi Elektronicznej Platformy Usług Administracji Publicznej ePUAP,

- ewidencjonowania działalności gospodarczej droga elektroniczna w ramach Centralnej Ewidencji i Informacji o Działalności Gospodarczej CEIDG,

- posługiwania się elektronicznymi aplikacjami urzedowymi - szkolenie skierowane do pracowników administracji publicznej ${ }^{8}$.

Ponadto użytkownik odwiedzający witryne może skorzystać z szybkich odsyłaczy do wybranych e-usług ePK (obejmujacych m.in.: załatwianie spraw administracyjnych przez Internet ${ }^{9}$, sprawdzanie statusu spraw w systemie oraz możliwość obejrzenia dokumentów związanych z daną sprawą), podwitryny WebNotarius, umożliwiającej weryfikację podpisów elektronicznych ${ }^{10}$, oraz przeglądu wiadomości $\mathrm{z}$ regionów ${ }^{11}$. Dodatkowo użytkownicy portalu mogą skorzystać z odnośnika „pomoc”, przenoszacego na strone działu Help Desk. Zadaniem owego działu jest udzielanie odpowiedzi na wszelkie pytania związane z problematyką prowadzenia działalności gospodarczej, zarówno w języku polskim, jak i angielskim. Zgłoszenia zostają przekierowane do kompetentnych organów zobligowanych do udzielenia rzeczowej odpowiedzi12.

Zgodnie $\mathrm{z}$ art. $22 \mathrm{~d} w$ celu umożliwienia uzyskania informacji o przepisach regulujących świadczenie usług poza terytorium Rzeczypospolitej Polskiej punkt kontaktowy powinien udostepniać informacje o adresach witryn punktów kontaktowych w innych państwach. W związku z powyższym w dolnej części strony głównej portalu umieszczono linki do pozostałych europejskich punktów kontaktowych znajdujących sie w sieci EU-GO (Matuszewska-Maroń i Łakomiak, 2013).

$\mathrm{Na}$ rysunku 2 przedstawiono ekran powitalny witryny www.biznes.gov.pl. 
Rysunek 2.
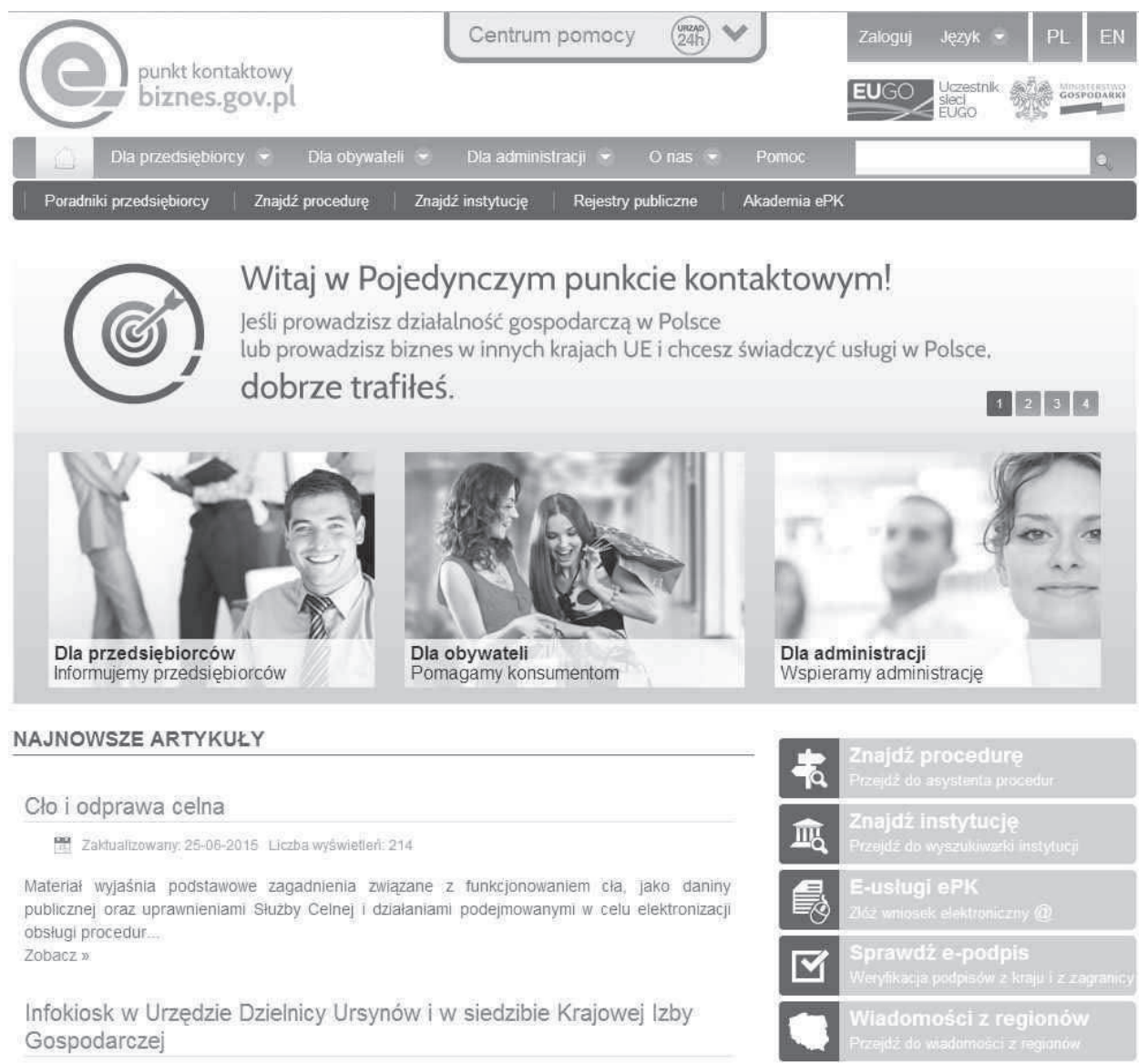

Źródło: PPK, www.biznes.gov.pl (25.06.2015).

Zgodnie z doniesieniami z prasy przedsiębiorcy bardzo cenią sobie możliwość personalizacji przy zadawaniu konkretnych zapytań oraz szczegółowe informacje odnoszące się do spisów procedur.

Te najbardziej skomplikowane docierają do ekspertów z Krajowej Izby Gospodarczej lub do odpowiednich urzędów. Najczęściej ludzie pytają, jak wypełnić formularz CEIDG. Wielu cudzoziemców spoza Unii chce wiedzieć, jak mają prowadzić działalność gospodarczą w Polsce (...) Do opcji przydatnych właścicielom firm należa też spisy procedur. Każda procedura, np. nadanie uprawnień budowlanych, wpis firmy do Krajowego Rejestru Sądowego czy też wniosek o potwierdzenie zatwierdzenia zaszeregowania obiektu hotelarskiego, jest dokładnie opisana - gdzie sie odbywa, jakie dokumenty trzeba złożyć, ile kosztuje. W wypadku procedur elektronicz- nych poprzez ePunkt można złożyć odpowiedni wniosek. Na platformie zarejestrowanych jest ponad 1200 starostw powiatowych i urzędów gminy. Można tu również zarejestrować jednoosobową działalność gospodarczą albo spółkę z ograniczoną odpowiedzialnością (Elektroniczny Punkt Kontaktowy, http).

\section{Porównanie rozwoju PPK w Polsce na tle innych państw EOG; dyskusja odnośnie do potencjalnych barier w rozwoju PPK w Polsce}

W dokumencie Single Market Scoreboard, Performance per governance tool, Points of Single Contact uwzględniono analize stopnia rozwoju Pojedynczych Punktów 
Kontaktowych w obszarze Europejskiej Unii Gospodarczej (EOG), uwzględniającej państwa członkowskie UE oraz państwa stowarzyszone (Islandia, Norwegia, Lichtenstein). Autorzy dokumentu zwracają uwagę na cztery elementy składowe łącznej oceny rozwoju e-usług dla przedsiębiorców w ramach PPK w poszczególnych państwach EOG:

1) jakość i dostępność informacji,

2) stopień kompletności e-procedur (w odniesieniu do ogółu procedur),

3) dostępność dla użytkowników z innych państw,

4) funkcjonalność dla użytkowników ${ }^{13}$.

$\mathrm{Na}$ podstawie danych zbiorczych stanowiących o ocenie stopnia rozwoju e-usług dla przedsiębiorców w poszczególnych państwach z obszaru EOG, zgodnie z przytoczoną charakterystyką, polska e-administracja dla przedsiębiorców została najgorzej oceniona pod kątem stopnia kompletności procedur. W pozostałych kategoriach sieć PPK w Polsce uzyskała wyniki przeciętne, plasujące ją w gronie przeciętnie rozwiniętych sieci PPK z byłych demoludów, jednak lepsze od najsłabiej ocenianych pod względem czterech przytoczonych kryteriów Bułgarii, Łotwy oraz Rumunii.

$\mathrm{Na}$ podstawie zgromadzonych danych cząstkowych autorzy raportu opracowali mapę rozwoju Pojedynczych Punktów Kontaktowych w poszczególnych państwach obszaru EOG. Analizując stopień rozwoju PPK w Polsce na tle innych państw obszaru EOG, można dojść do wniosku, że system ten rozwija się w stopniu przeciętnym. Problemy, jakie napotyka się zarówno w Polsce, jak i w większości innych państw EOG dotyczą małego odsetka procedur dostępnych on-line, w szczególności w odniesieniu do cudzoziemców, spotykających się $\mathrm{z}$ barierami w postaci braku wsparcia technicznego przy weryfikacji podpisów elektronicznych, w praktyce uniemożliwiającego wypełniania e-procedur (Single Market Scoreboard (http). Eliminacja tych barier stanowi istotne wyzwanie dla sieci EU-GO w najbliższych latach.

\section{Zakończenie}

Autor, odnosząc się do postawionego we wstępie założenia badawczego: elektronizacja procesu podejmowania, wykonywania i zakańczania dziatalności gospodarczej za pośrednictwem Pojedynczego Punktu Kon- taktowego napotyka w Polsce liczne bariery zwiazane $z$ niedostosowanie krajowego ustawodawstwa do potrzeb dynamicznie zmieniajacej się gospodarki, istotnie wptywajace na ograniczenie rozwoju e-ustug dla przedsiębiorców $w$ porównaniu z innymi państwami Unii Europejskiej, po uwzględnieniu danych natury zarówno legislacyjnej, technologicznej, jak i społecznej zawartych w niniejszej publikacji, weryfikuje je twierdząco.

Odnosząc się do polskiej specyfiki, należałoby uwzględnić najistotniejsze źródło problemów w rozwoju PPK natury prawnej, jakim jest niedostosowane do przemian technologicznych ustawodawstwo krajowe, w szczególności wymóg pisemności rozumiany jako alternatywa do formy elektronicznej. Zgodnie z art. 14 § 1 Ustawy z dnia 14 czerwca 1960 r. Kodeks postępowania administracyjnego, ustawodawca odróżnia formę pisemną od e-dokumentu. Wymóg złożenia wniosku w formie papierowej nie uwzględnia jednocześnie możliwości złożenia owego dokumentu w innej formie (za: Matuszewska-Maroń i Łakomiak, 2013) ${ }^{14}$. Podobny problem dotyczy wymaganych ustawowo załączników do poszczególnych wniosków w większości procedur administracyjnych, co w praktyce uniemożliwiają pełne wdrożenie e-procedur. Można więc wnioskować, że warunkiem eliminacji barier w elektronizacji procesu podejmowania, wykonywania i zakończania działalności gospodarczej za pośrednictwem Pojedynczego Punktu Kontaktowego, jest istotna nowelizacja polskiego prawa. Ponadto równie istotne jest stosowanie wzorców dobrych praktyk, zaczerpniętych $\mathrm{z}$ innych państw implementujących Pojedyncze Punkty Kontaktowe w stopniu najbardziej zaawansowanym (Holandia, Wielka Brytania, Szwecja, Dania, Estonia, Hiszpania).

\section{Przypisy}

1 Ustawa z dnia 2 lipca 2004 r. o swobodzie działalności gospodarczej, Dz. U. z 2004 r. Nr 173 poz. 1807 .

2 Ibidem.

3 Dyrektywa 2006/123/WE Parlamentu Europejskiego i Rady z 12 grudnia 2006 r. dotycząca usług na rynku wewnętrznym, Dz. Urz. L 376 , 27.12.2006 r.; https://www.biznes.gov.pl/pl/ dyrektywa-uslugowa

4 https://ewnioski.biznes.gov.pl/suppliant/upage/ general/new_case.page (25.06.2015).

5 Podpis elektroniczny bezpieczny (kwalifikowany) występuje w formie danych dołączanych 
do podpisywanego dokumentu w wersji elektronicznej, jednoznacznie identyfikując osobę podpisująca na podstawie wystawionego dla niej certyfikatu kwalifikowanego i odpowiadającym kluczom kryptograficznym - publicznego i prywatnego. Profil zaufany to bezpłatna metoda weryfikacji tożsamości użytkownika ePUAP (zestaw informacji identyfikujących i opisujących użytkownika potwierdzony przez jeden z punktów potwierdzających), za: Mamrot i Kośmider (2012, s. 12-15).

6 Warto podkreślić, że opisy procedur administracyjnych zostały utworzone zgodnie z ustandaryzowanym wzorem, uwzględniającym opis procedury z podstawowymi informacjami odnoszącymi się m.in. do nazwy procedury, urzędu ją realizującego, celu, rodzaju, PKD, ustawowego czasu realizacji, uczestników, warunków wejściowych, rezultatów, aktów prawnych, środków odwoławczych, przebiegu procedury oraz procedur powiązanych $\mathrm{z}$ daną procedurą. za: Matuszewska-Maroń i Łakomiak (2013).

7 Kategoria ta obejmuje m.in. Inspektoraty Weterynarii, Stacje Sanitarno-Epidemiologiczne, Urzędy i Izby Celne, Urzędy i Izby Morskie, Jednostki Certyfikujące, Komendy Państwowej Straży Pożarnej, Komendy Policji, Kuratoria Oświaty, Oddziały Urzędu Dozoru Technicznego, Okręgowe Inspektoraty Pracy, Okręgowe Inspektoraty Rybołówstwa Morskiego, Okręgowe Izby (Aptekarskie, Architektów, Inżynierów Budownictwa, Lekarskie, Lekarsko-Weterynaryjne, Pielęgniarek i Położnych, Radców Prawnych, Urbanistów, Urbanistów), Okręgowe Rady Adwokackie, Okręgowe Urzędy Górnicze, Państwowe Instytucje Kultury, Inspektoraty Nadzoru Budowlanego, Inspektoraty Weterynarii, Regionalne Dyrekcje (Lasów Państwowych, Ochrony Środowiska), Regionalne Zarządy Gospodarki Wodnej, Specjalne Strefy Ekonomiczne, Urzędy Regulacji Energetyki, Urzędy Statystyczne, Urzędy Zeglugi Sródlądowej, Wojewódzkie Inspekcje Handlowe, Wojewódzkie Inspektoraty (Farmaceutyczne, Jakości Handlowej Artykułów Rolno-Spożywczych, Ochrony Roślin i Nasiennictwa, Ochrony Środowiska), Wojewódzkie Urzędy (Ochrony Zabytków, Pracy), Wojewódzkie Zarządy Dróg, za: https://www.biznes.gov.pl/szukaj-instytucji (25.06.2015); wyszukiwarka zawiera dane ponad 6200 instytucji; za: Matuszewska-Maroń i Łakomiak (2013).

8 https://www.biznes.gov.pl (25.06.2015).

9 https://ewnioski.biznes.gov.pl/suppliant/landing page.page (25.06.2015)

10 https://standardva.webnotarius.eu/dvcs-client/ load document.dvcs? conversation Id $=8760$ (25.06.2015).

11 https://www.biznes.gov.pl/regiony (25.06.2015).

12 https://www.biznes.gov.pl/pomoc (25.06.2015), za: (Matuszewska-Maroń i Lakomiak, 2013).
13 Ang. usability; za: Single Market Scoreboard (http).

14 Za: Matuszewska-Maroń i Łakomiak (2013).

\section{Bibliografia}

Brooke, J. (1996). SUS: a "quick and dirty" usability scale. W: P.W. Jordan, B. Thomas, B.A. Weerdmeester i A.L. McClelland (red.), Usability Evaluation in Industry. London: Taylor and Francis.

Bwayla, K.J. i Zulu, S. (2012). Handbook of Research on E-Government in Emerging Economies: Adoption, E-Participation and Legal Frameworks. Information Science Reference (IGI Global), USA.

Czubała, A., Jonas, A., Smoleń, T. i Wiktor, J.W. (2006). Marketing ustug. Kraków: Oficyna Ekonomiczna.

Dąbrowska, A., Janoś-Kresło, M. i Wódkowski, A. (2009). E-ustugi a społeczeństwo informacyjne. Warszawa: Difin.

Dyrektywa 2006/123/WE Parlamentu Europejskiego i Rady z 12 grudnia 2006 r. dotycząca usług na rynku wewnętrznym, Dz. Urz. L 376, 27.12.2006 r.

Elektroniczny Punkt Kontaktowy: odpowiada na prawie wszystkie pytania firm, http://wyborcza.biz/biznes/1,101562,15445184,Elektroniczny_Punkt_Kontaktowy_Odpowiada_na_prawie.html (20.06..2015).

Gilmore, A. (2006). Marketing i zarzadzanie. Warszawa: PWE.

Grytner, R.A. (2006). Zintegrowane Biblioteki Procedur - narzędzie do budowy taniej, sprawnej i nowoczesnej administracji publicznej. Elektroniczna Administracja, 2(3).

https://standardva.webnotarius.eu/dvcs-client/load document.dvcs? conversationId $=8760$ (25.06.2015).

Jezierska, A. (2006). System informatyczny w urzędzie. Gazeta Prawna, 82.

Kotler, P. (1982). Principles of Marketing. Englewood Cliffs.

Karaszewski, R. (2006). Nowe koncepcje zarzadzania jakościa. Toruń: Wyd. Dom Organizatora.

Komorowski, S., Koralewski, M., Kośmider, A., Kraska, M., Langer, J., Nowaczyk, K., Pucher, J., Mamrot, Sz. i Kośmider, A. (2012). Jak skutecznie biznes może wykorzystać rozwiazania e-administracji. Warszawa: Polska Agencja Rozwoju Przedsiębiorczości, http://parp.gov.pl.

Mańkowska, N. (2014). E-administracja a efektywność sektora publicznego. Prace Naukowe Uniwersytetu Ekonomicznego we Wroctawiu.

Matuszewska-Maroń, M. i Łakomiak, M. (2013). Pojedynczy Punkt Kontaktowy - funkcjonalności dla administracji i przedsiębiorców. e-mentor, 1(48). http://www.e-mentor.edu.pl/artykul/index/ numer/48/id/995 (20.06.2015). 
Papaj, T. (2012). Instrumenty e-administracji jako innowacje w koncepcji Public Governance. Wspótczesne Zarzadzanie, 2, 150-159.

Payne, A. (1997). Marketing ustug. Warszawa: PWE.

Rozwój sektora e-ustug na świecie. http://parp.gov. pl (20.06.2015).

Rozporządzenie Ministra Rozwoju Regionalnego z dnia 29 stycznia 2009 roku, Dz. U. z 2009 r. Nr 21, poz. 115 .

Sikora, M. (2004). Polska droga do e-administracji. Uwagi na temat procesu tworzenia administracji elektronicznej. W: Obywatel w lokalnej spoteczności. Studia i szkice socjologiczne. Tychy-Opole: WSZiNS i Uniwersytet Opolski.
Single Market Scoreboard, Performance per governance tool, Points of Single Contact, EU Internal Market and Services. http://ec.europa.eu/singlemarket-scoreboard (20.06.2015).

Stanton, W.J. (1981). Fundamentals of Marketing. New York.

Śliwiński, M., Modele biznesowe e-ustug. http://parp. gov.pl (20.06.2015).

Ustawa z dnia 2 lipca 2004 r. o swobodzie działalności gospodarczej, Dz. U. z 2004 r. Nr 173, poz. 1807. www.biznes.gov.pl (pozyskano 25.06.2015).

Ziemba, E. (2012). Miejsce e-administracji w kreowaniu społeczeństwa informacyjnego - teoria i praktyka. Collegium of Economic Analysis. 